\title{
Comparative analyses reveal discrepancies among results of commonly used methods for Anopheles gambiaemolecular form identification
}

\author{
Federica Santolamazza', Beniamino Caputo', Maria Calzetta', José L Vicente², Emiliano Mancini', \\ Vincenzo Petrarca ${ }^{3}$, João Pinto ${ }^{2}$ and Alessandra della Torre ${ }^{1 *}$
}

\begin{abstract}
Background: Anopheles gambiae M and S molecular forms, the major malaria vectors in the Afro-tropical region, are ongoing a process of ecological diversification and adaptive lineage splitting, which is affecting malaria transmission and vector control strategies in West Africa. These two incipient species are defined on the basis of single nucleotide differences in the IGS and ITS regions of multicopy rDNA located on the X-chromosome. A number of PCR and PCR-RFLP approaches based on form-specific SNPs in the IGS region are used for $\mathrm{M}$ and $\mathrm{S}$ identification. Moreover, a PCR-method to detect the M-specific insertion of a short interspersed transposable element (SINE200) has recently been introduced as an alternative identification approach. However, a large-scale comparative analysis of four widely used PCR or PCR-RFLP genotyping methods for $\mathrm{M}$ and S identification was never carried out to evaluate whether they could be used interchangeably, as commonly assumed.
\end{abstract}

Results: The genotyping of more than 400 A. gambiae specimens from nine African countries, and the sequencing of the IGS-amplicon of 115 of them, highlighted discrepancies among results obtained by the different approaches due to different kinds of biases, which may result in an overestimation of MS putative hybrids, as follows: i) incorrect match of $\mathrm{M}$ and $\mathrm{S}$ specific primers used in the allele specific-PCR approach; ii) presence of polymorphisms in the recognition sequence of restriction enzymes used in the PCR-RFLP approaches; iii) incomplete cleavage during the restriction reactions; iv) presence of different copy numbers of M and S-specific IGS-arrays in single individuals in areas of secondary contact between the two forms.

Conclusions: The results reveal that the PCR and PCR-RFLP approaches most commonly utilized to identify $A$. gambiae $\mathrm{M}$ and $\mathrm{S}$ forms are not fully interchangeable as usually assumed, and highlight limits of the actual definition of the two molecular forms, which might not fully correspond to the two A. gambiae incipient species in their entire geographical range. These limits are discussed and operational suggestions on the choice of the most convenient method for large-scale $\mathrm{M}$ - and S-form identification are provided, also taking into consideration technical aspects related to the epidemiological characteristics of different study areas.

\section{Background}

The mosquito vector species responsible for most Plasmodium falciparum-malaria transmission in subSaharan Africa, Anopheles gambiae sensu stricto (hereafter $A$. gambiae), is ongoing a process of ecological diversification and adaptive lineage splitting which is

\footnotetext{
* Correspondence: ale.dellatorre@uniroma1.it

'Istituto Pasteur-Fondazione Cenci-Bolognetti, Dipartimento di Sanità Pubblica e Malattie Infettive, Università SAPIENZA, Piazzale Aldo Moro 5 , 00185, Rome, Italy

Full list of author information is available at the end of the article
}

changing patterns of malaria transmission and affecting vector control strategies in West Africa [1-4]. Two morphologically indistinguishable incipient species (provisionally named $\mathrm{M}$ and $\mathrm{S}$ molecular forms) have been described within A. gambiae, based on form-specific single nucleotide polymorphisms (SNPs) on the intergenic spacer (IGS) and internal transcribed spacer (ITS) regions of multicopy ribosomal DNA (rDNA) located on the X-chromosome [5,6]. S-form is distributed across sub-Saharan Africa and breeds mostly in association with rain-dependent pools and temporary puddles. M-

\section{(Ciomed Central}


form distribution overlaps with that of S-form in West and Central Africa, but the former form is apparently absent east of the Great Rift Valley; it is able to exploit relatively more permanent breeding sites, often closely associated with human activities, such those created by irrigation, rice cultivation and urbanization $[2,3,7,8]$. This adaptation allows the M-form to breed throughout the year, thus causing a shift from seasonal to yearround malaria transmission. Importantly, genetic traits conferring resistance to insecticides commonly used against these vectors are differently distributed between the two forms $[9,10]$.

Genetic divergence between $\mathrm{M}$ and $\mathrm{S}$ forms has been recently shown to be widespread across the genome [11,12]. However, the most widely used methods for $\mathrm{M}$ and $\mathrm{S}$ specimen identification are based on genotyping procedures for the form-specific SNPs in the IGS rDNA region on the centromere of the $\mathrm{X}$-chromosome. These are performed either by PCR using form-specific primers [13,14] or PCR-RFLP [15-17] (Figure 1). More a)

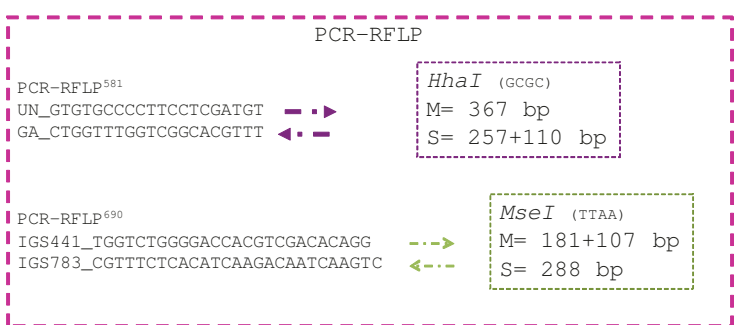

b)

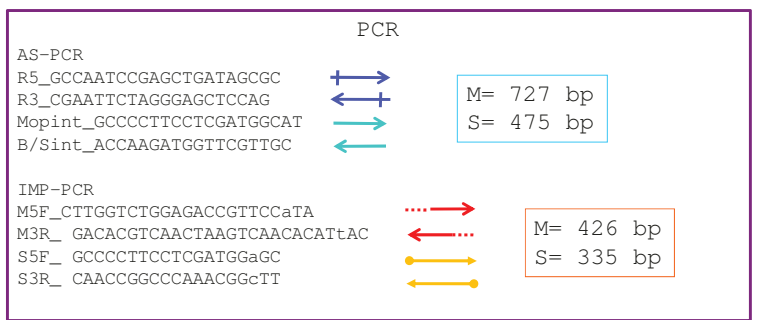

C)

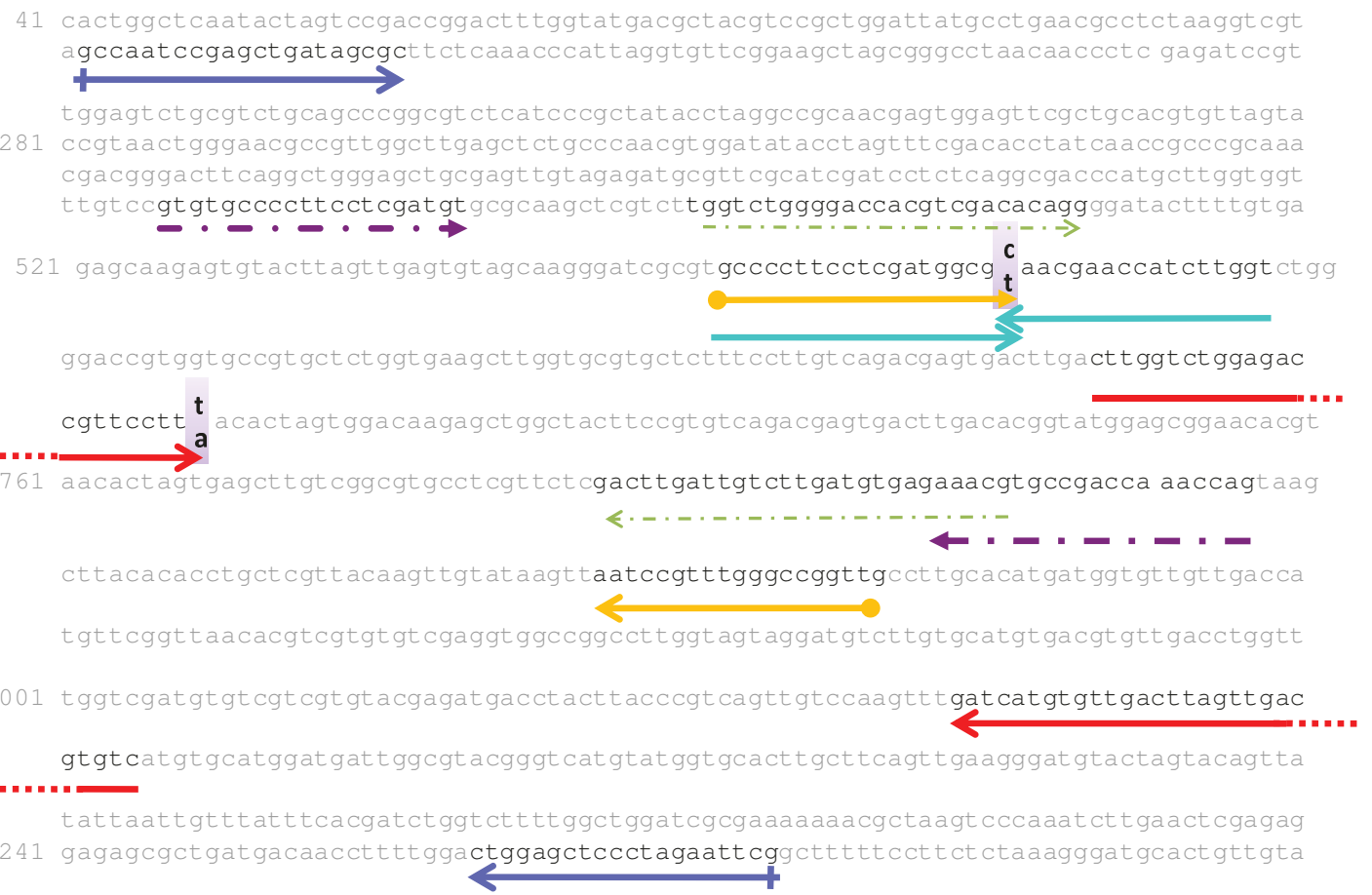

Figure 1 Sequence and alignment of $\mathbf{M}$ and $\mathbf{S}$ Anopheles gambiae molecular form specific diagnostic primers. a) Primer sequences, restriction enzymes and $M$ and $S$ Anopheles gambiae molecular form specific products from PCR-RFLP ${ }^{581}[16]$ and PCR-RFLP $P^{690}[16,17]$; b) primer sequences and molecular form-specific products as in AS-PCR [13] and IMP-PCR [14]; C) location of primer pairs and restriction sites utilized in AS-PCR and PCR-RFLPS are reported on the 28S (from 41 to 400) IGS sequence (from 401 to 1321) (AF470093-AF470116; [29]). 
recently, a PCR-method to detect the M-specific insertion of a SINE200 (short interspersed transposable element), mapping about $1 \mathrm{Mb}$ apart from IGS SNPs in the chromosome-X centromeric region, was also developed [18]. Results from large scale identification of $A$. gambiae field specimens by means of any of these approaches highlighted the virtual absence of hybrid M/ $\mathrm{S}$ patterns, thus contributing substantial evidence of $\mathrm{M}$ and $\mathrm{S}$ reproductive isolation in nature. However, high frequencies of M/S IGS-patterns have been recently reported from The Gambia [19] and Guinea Bissau [20]. A preliminary comparison of different identification approaches in samples from these westernmost geographical areas highlighted inconsistencies in the results and the occurrence of possible biases due to the routine practice of identifying $\mathrm{M}$ and $\mathrm{S}$ mosquitoes based on a single assay [21].

The results of a large-scale comparative analysis of four widely used PCR or PCR-RFLP genotyping methods for $\mathrm{M}$ and $\mathrm{S}$ identification provide operational recommendations to medical entomologists dealing with $\mathrm{M}$ and $\mathrm{S}$ identification in the Afrotropical region.

\section{Methods}

\section{Samples, genotyping and sequencing}

Table 1 lists the indoor-resting female samples processed in this study, the dates of collections and the numbers of specimens genotyped. Figure 2 shows the location of the sampling sites. The specimens from Guinea Bissau and The Gambia [21] were selected based on inconsistent results from IGS [16] and SINE200 insertion [18] genotyping.

DNA was extracted from either legs or other parts of the carcasses not including the abdomen, to avoid possible biases associated to the risk of contamination with DNA from sperm harboured in spermathecae.

Anopheles gambiae samples were first identified based on results from PCR-RFLP approach (from now on

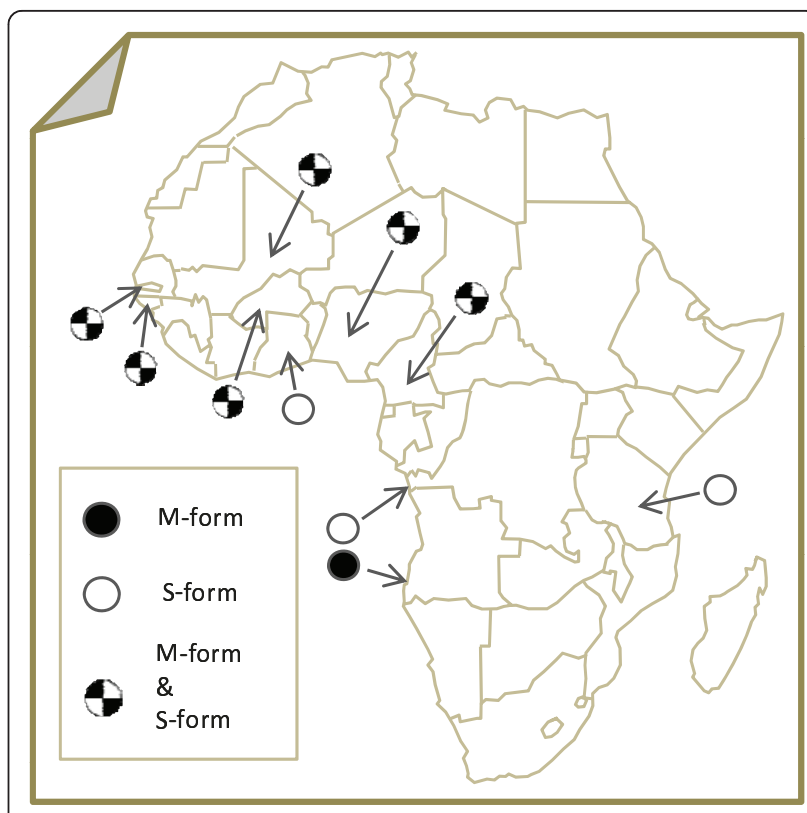

Figure 2 Location of collection sites. Black and white pies indicate the exclusive presence of either $\mathrm{M}$ or $\mathrm{S}$ Anopheles gambiae molecular forms, respectively. Black/white pies indicate sites where both molecular forms were sampled.

PCR-RFLP $\left.{ }^{581}\right)$ recognizing a T/C SNP $(\mathrm{T}=\mathrm{M}$-form; $\mathrm{C}$ $=\mathrm{S}$-form) at position 581 of IGS rDNA region (from now on IGS $\left.{ }^{581}[16]\right)$. Subsequently, the following genotyping approaches were applied (Figure 1 shows the position of primers and restriction sites on the IGS amplicon sequence): i) the PCR-RFLP approach (from now on PCR-RFLP $\left.{ }^{690}\right)$ recognizing a A/T SNP $(\mathrm{A}=\mathrm{M}$ form; $\mathrm{T}=\mathrm{S}$-form) at position 690 of IGS $\mathrm{rDNA}$ region (from now on IGS ${ }^{690}$ [17]); ii) the PCR approach using allele-specific primers designed to detect the IGS ${ }^{581}$ SNP (from now on AS-PCR [13]); iii) the PCR approach based on the specific and irreversible single-locus insertion of a SINE200 transposable element in the $\mathrm{X}$ -

Table 1 Collection sites of analysed Anopheles gambiae s.s. indoor-resting female samples, and references to published papers.

\begin{tabular}{|c|c|c|c|c|c|c|}
\hline Countries & Collection sites & Longitude & Latitude & Year of collection & $\mathbf{N}$ & Reference \\
\hline Tanzania & Nyakariro, Kwagole & $05^{\circ} 05^{\prime}, 02^{\circ} 30^{\prime} \mathrm{S}$ & $39^{\circ} 08^{\prime}-33^{\circ} 27^{\prime} E$ & 1997-98 & 28 & {$[7]$} \\
\hline Angola & Cabinda, Luanda & $05^{\circ} 32^{\prime}, 08^{\circ} 50^{\prime} \mathrm{S}$ & $12^{\circ} 11^{\prime}, 13^{\circ} 14^{\prime} \mathrm{E}$ & 2003 & 64 & {$[30]$} \\
\hline Cameroon & Mangoum, Kribi & $05^{\circ} 31^{\prime}-02^{\circ} 56^{\prime} \mathrm{N}$ & $9^{\circ} 54^{\prime}-10^{\circ} 37^{\prime} \mathrm{E}$ & 2005-06 & 47 & {$[18]$} \\
\hline Nigeria & Kobape, Olugbo & $07^{\circ} 00^{\prime}-07^{\circ} 20^{\prime} \mathrm{N}$ & $03^{\circ} 00^{\prime}-03^{\circ} 30^{\prime} \mathrm{E}$ & 2001 & 27 & {$[31]$} \\
\hline Burkina Faso & Bobo Dioulasso & $11^{\circ} 02^{\prime} \mathrm{N}$ & $04^{\circ} 13^{\prime} \mathrm{W}$ & 2001 & 58 & {$[7]$} \\
\hline Mali & Banambani & $12^{\circ} 48^{\prime} \mathrm{N}$ & $08^{\circ} 03^{\prime} \mathrm{W}$ & 1996 & 39 & {$[7]$} \\
\hline Ghana & Accra area & $05^{\circ} 38^{\prime} \mathrm{N}$ & $00^{\circ} 15^{\prime} \mathrm{W}$ & 2002 & 45 & {$[18]$} \\
\hline \multirow[t]{2}{*}{ Guinea Bissau } & Antula & $11^{\circ} 5^{\prime} \mathrm{N}$ & $15^{\circ} 30^{\prime} \mathrm{W}$ & 1995 & 32 & {$[20]$} \\
\hline & & & & 2007 & 35 & {$[20]$} \\
\hline The Gambia & Kartong, Sare Samba Sowe & $13^{\circ} 05^{\prime}-13^{\circ} 34^{\prime} \mathrm{N}$ & $16^{\circ} 45^{\prime}-15^{\circ} 54^{\prime} \mathrm{W}$ & 2006 & 49 & {$[19]$} \\
\hline
\end{tabular}

$\mathrm{N}=$ number of specimens/sample. 
chromosome centromeric region (from now on SINEPCR [18]), about $1 \mathrm{Mb}$ from the IGS rDNA region including the IGS form-specific SNPs. A sub-sample of specimens from Angola, Burkina Faso, The Gambia and Guinea Bissau were also identified by a PCR approach utilizing Intentional Mismatch Primers containing single base mismatches at the third nucleotide from their 3' end (from now on IMP-PCR[14]).

An IGS fragment of 367 bp (from now on "IGS-amplicon") was amplified using UN and GA primers by Fanello et al [16] (Figure 1) from selected specimens and sequenced using ABI Big Dye Terminator v.2 chemistry and an ABI Prism 3700 DNA Analyser. Chromatograms were inspected for double peaks by eye. PCR and sequence analyses were carried out in Rome and/or Lisbon. Selected samples were analysed in both laboratories for results validation.

\section{Statistical analyses}

QSVanalyzer software - which allows the extraction of quantitative sequence variant (QSV) information from sequence electropherograms - was applied to estimate the relative proportions of the double peaks (i.e., copy number proportions: CNP)[22]) observed in electropherograms of IGS amplicon at positions 581 [16] (hereafter $\mathrm{CNP}^{581}$ ) and 690 [17] (hereafter $\mathrm{CNP}^{690}$ ) in sequences of the IGS locus from single A. gambiae specimens. The programme analyses each trace and adjusts it in relation to the peak heights of upstream/downstream nucleotides, allowing rapid batchwise analysis of DNA sequence traces for estimation of the relative proportions of two QSVs at a given site. Kruskal-Wallis and multiple comparison tests were carried out by STATISTICA 6.1 (StatSoft, Inc. 2003).

\section{Results}

Four-hundred-twenty-four A. gambiae specimens from nine African countries by PCR-RFLP ${ }^{581}$, PCR-RFLP ${ }^{690}$, AS-PCR and SINE-PCR were genotyped (Table 1). Most (97\%) of the specimens were consistently identified by all approaches in samples from Tanzania to Ghana $(\mathrm{N}=$ 250), while the percentage of consistent identifications was lower (46\%) in samples from Guinea Bissau and The Gambia - which were selected based on previous inconsistent results from PCR-RFLP ${ }^{581}$ and SINE-PCR [21] - and in samples from Burkina Faso (41\%). Inconsistent identifications were confirmed at least twice by PCR and PCR-RFLP genotyping carried out in different laboratories. The IGS-amplicon was sequenced in 115 specimens (Angola $\mathrm{N}=5$; Cameroon $\mathrm{N}=1$; Nigeria $\mathrm{N}$ = 1; Burkina Faso N = 16; Mali $\mathrm{N}=1$; Guinea Bissau N = 62; The Gambia $N=29$ ). The latter samples plus additional 110 specimens (Tanzania $\mathrm{N}=11$; Angola $\mathrm{N}=$ 21; Cameroon $\mathrm{N}=9$; Nigeria $\mathrm{N}=11$; Burkina Faso $\mathrm{N}=$
20; Mali $\mathrm{N}=12$; Ghana $\mathrm{N}=18$; Guinea Bissau $\mathrm{N}=1$; The Gambia $N=7$ ), were also genotyped by IMP-PCR.

The results were as follows:

Tanzania. All specimens were consistently identified as $\mathrm{S}$-form by the four approaches utilized. Eleven identifications were confirmed also by IMP-PCR.

Angola. All individuals from Cabinda $(\mathrm{N}=32)$ were identified as $\mathrm{S}$-form by the four approaches. Twentyseven out of 32 individuals from Luanda were identified as $\mathrm{M}$-form by all approaches, while five of them showed a $\mathrm{MS}^{690}$ heterozygous pattern. Sequence analysis of these specimens revealed the presence of an $\mathrm{A} / \mathrm{C}$ polymorphism at position 690 (instead of the expected A/T polymorphism, corresponding to the MseI restriction site), which does not allow the form-specific cleavage of the PCR-amplified band. Ten M- (including the above 5) and $11 \mathrm{~S}$-identifications were confirmed also by IMPPCR.

Cameroon. Twenty individuals were consistently identified as M-form and 26 as $\mathrm{S}$-form. One single specimen showed a $\mathrm{MS}^{690}$ pattern, but a $\mathrm{M}$-form pattern by the other approaches. IMP-PCR and IGS-sequencing confirmed the MM genotype.

Nigeria. Nine individuals were consistently identified as $\mathrm{M}$-form and 17 as $\mathrm{S}$-form. One single specimen showed a S-pattern by both PCR-RFLPs and MS by ASPCR. IMP-PCR and IGS-sequencing confirmed the SS genotype.

Burkina Faso. Eleven individuals were consistently identified as $\mathrm{M}$-form and 13 as $\mathrm{S}$-form; 32 specimens $\left(\mathrm{MM}^{581}-\mathrm{MM}^{690}=17\right.$ and $\left.\mathrm{SS}^{581}-\mathrm{SS}^{690}=15\right)$ showed $\mathrm{a}$ MS-pattern only by AS-PCR. The PCR-RFLP genotypes were confirmed either by IMP-PCR and/or by sequencing of the IGS-amplicon, which did not reveal any MSheterozygous pattern. Two $M^{581}-M^{690}$ specimens were found, one showing MS-AS-PCR, the other one showing M-AS-PCR pattern. Both were genotyped as MM by IMP-PCR and IGS-sequencing.

Mali. Three individuals were consistently identified as M-form and 35 as S-form. One single specimen showed a MS-pattern by AS-PCR and a M-form pattern by the other approaches: both IMP-PCR and IGS-sequencing confirmed the MM genotype.

Ghana. All specimens were consistently identified as S-form by the four approaches utilized.

Guinea Bissau. Results from PCR-RFLP ${ }^{581}$, PCRRFLP $^{690}$, AS-PCR and sequencing are shown in Table 2: $61 \%(41 / 67)$ of the specimens showed consistent genotypes with the three approaches (i.e. $5 \mathrm{M}, 29 \mathrm{MS}, 7 \mathrm{~S}$; Table 2, lines 1, 5, 10). PCR-RFLP ${ }^{581}$ and PCR-RFLP ${ }^{690}$ patterns were congruent in $73 \%(49 / 67$, lines 1,2 , $5,7,10)$ of the specimens: the remaining were either $\mathrm{MM}^{581}-\mathrm{MS}^{690}$ (10\%; lines 3 and 4) or $\mathrm{MS}^{581}-\mathrm{SS}^{690}$ (16\%, lines 6, 8 and 9). No opposite $\mathrm{MM}^{581}-\mathrm{SS}^{690}$ nor $\mathrm{SS}^{581}$ - 
Table 2 Results of identification of Anopheles gambiae s. s. indoor-resting female samples by different genotyping approaches

\begin{tabular}{|c|c|c|c|c|c|c|c|}
\hline \multirow[t]{2}{*}{ Samples } & \multicolumn{3}{|c|}{ PCR-RFLPs } & \multirow[b]{2}{*}{$\begin{array}{l}\text { AS- } \\
\text { PCR }\end{array}$} & \multirow[b]{2}{*}{$N(n)$} & \multicolumn{2}{|c|}{ Sequencing } \\
\hline & & $I_{G} S^{581}$ & $\mathrm{IGS}^{690}$ & & & $I G S^{581}$ & $I G S^{690}$ \\
\hline \multirow{10}{*}{$\begin{array}{l}\text { GUINEA } \\
\text { BISSAU }\end{array}$} & 1 & MM & MM & MM & $5(4)$ & $\mathrm{T}$ & A \\
\hline & 2 & MM & MM & MS & $6(3)$ & $\mathrm{T}$ & A \\
\hline & 3 & MM & MS & MS & 1 & $\mathrm{~T}$ & A \\
\hline & 4 & MM & MS & MS & 6 & $\mathrm{~T} / \mathrm{C}$ & $\mathrm{A} / \mathrm{T}$ \\
\hline & 5 & MS & MS & MS & $\begin{array}{c}29 \\
(28)\end{array}$ & $\mathrm{T} / \mathrm{C}$ & $\mathrm{A} / \mathrm{T}$ \\
\hline & 6 & MS & SS & MS & 6 & $\mathrm{~T} / \mathrm{C}$ & $\mathrm{A} / \mathrm{T}$ \\
\hline & 7 & SS & SS & MS & 2 & $\mathrm{~T} / \mathrm{C}$ & $\mathrm{A} / \mathrm{T}$ \\
\hline & 8 & MS & SS & MS & 1 & C & $\mathrm{T}$ \\
\hline & 9 & MS & SS & SS & 4 & C & $\mathrm{T}$ \\
\hline & 10 & SS & SS & SS & 7 & C & $\mathrm{T}$ \\
\hline \multirow{10}{*}{ THE GAMBIA } & 11 & MM & MM & MM & $9(4)$ & $\mathrm{T}$ & A \\
\hline & 12 & MM & MM & MS & $7(4)$ & $\mathrm{T}$ & A \\
\hline & 13 & MM & MS & MM & 1 & $\mathrm{~T}$ & A \\
\hline & 14 & MM & MS & MS & 1 & $\mathrm{~T}$ & A \\
\hline & 15 & MM & MS & MS & 2 & $\mathrm{~T} / \mathrm{C}$ & $\mathrm{A} / \mathrm{T}$ \\
\hline & 16 & MS & MS & MS & $16(8)$ & $\mathrm{T} / \mathrm{C}$ & $\mathrm{A} / \mathrm{T}$ \\
\hline & 17 & MS & SS & MS & 1 & $\mathrm{~T} / \mathrm{C}$ & $\mathrm{A} / \mathrm{T}$ \\
\hline & 18 & MS & SS & MS & 2 & $C$ & $\mathrm{~T}$ \\
\hline & 19 & SS & SS & MS & 1 & C & $\mathrm{T}$ \\
\hline & 20 & SS & SS & SS & $9(5)$ & C & $\mathrm{T}$ \\
\hline
\end{tabular}

PCR-RFLP ${ }^{581}$ [16], PCR-RFLP ${ }^{690}$ [17] and AS-PCR [13] genotyping and sequencing of IGS amplicon. IGS ${ }^{581}$ : M-form $=\mathrm{T}$, S-form $=\mathrm{C}_{;} \mathrm{IGS}^{690}$ : M-form = A, S-form $=\mathrm{T}$. $\mathrm{N}=$ numbers of specimens identified by PCR-RFLPs and AS$P C R .(n)=$ number of specimens sequenced, when these do not correspond to $\mathrm{N}$.

$\mathrm{MM}^{690}$ identifications were observed. An AS-PCR heterozygous MS pattern was obtained from: i) all specimens genotyped as heterozygotes by at least one PCRRFLP, with the exception of four $\mathrm{MS}^{581}-\mathrm{SS}^{690}$ specimens showing a SS AS-PCR pattern (line 9); ii) 6 out of 11 $\mathrm{MM}^{581}-\mathrm{MM}^{690}$ homozygotes (line 2); and iii) 2 out of 9 $\mathrm{SS}^{581}-\mathrm{SS}^{690}$ (line 7). A match between the results of SINE-PCR and IGS genotypes (as defined by either consistent results of the different genotyping approaches and/or by direct sequencing of the IGS-amplicon, see below) was observed in 69\% of the specimens (46/67: 10 MM, $25 \mathrm{MS}$ and $11 \mathrm{SS}$ ). The mismatches were either due to SS (16/21) and MM (1/21) SINE-homozygotes with a heterozygous $\mathrm{MS}^{\mathrm{IGS}}$ genotype, and to MS SINEheterozygotes with a homozygous $\mathrm{MM}^{\mathrm{IGS}}(1 / 21)$ or $\mathrm{SS}^{\mathrm{IGS}}(3 / 21)$ genotype.

The Gambia. Results from PCR-RFLP ${ }^{581}$, PCRRFLP $^{690}$, AS-PCR and sequencing are shown in Table 2: $69 \%(34 / 49)$ of the specimens analysed showed consistent genotypes with the three approaches (i.e. $9 \mathrm{M}, 16$ MS, 9 S; Table 2, lines 11, 16, 20). PCR-RFLP ${ }^{581}$ and
PCR-RFLP ${ }^{690}$ patterns were congruent in $86 \%(42 / 49)$ of the specimens. The remaining were either $\mathrm{MM}^{581}$ $\mathrm{MS}^{690}$ (8\%; lines 13-15) or $\mathrm{MS}^{581}-\mathrm{SS}^{690}$ (6\%; line 17-18). No $\mathrm{MM}^{581}-\mathrm{SS}^{690}$ nor $\mathrm{SS}^{581}-\mathrm{MM}^{690}$ genotypes were observed. An AS-PCR heterozygous MS pattern was obtained for: i) all specimens genotyped as heterozygotes by at least one PCR-RFLP, with the exception of one $\mathrm{MM}^{581}$-MS $^{690}$ specimens showing a MM AS-PCR pattern (line 13); ii) 7 out of $16 \mathrm{MM}^{581}-\mathrm{MM}^{690}$ homozygotes (line 12) and 1 out of $10 \mathrm{SS}^{581}-\mathrm{SS}^{690}$ (line 19). A match between the results of SINE-PCR and IGS genotype (as defined from consistent results of the different genotyping approaches and/or by direct sequencing of the IGS-amplicon, see below) was observed in $72 \%$ of the specimens $(\mathrm{N}=36: 16 \mathrm{MM}, 9 \mathrm{MS}$ and $11 \mathrm{SS})$. The mismatches were either due to SS (9/13) and MM (1/ 13) SINE-homozygotes with a heterozygous $\mathrm{MS}^{\mathrm{IGS}}$ genotype or to MS SINE-heterozygotes with $\mathrm{MM}^{\mathrm{IGS}}(2 / 13)$ or $\mathrm{SS}^{\mathrm{IGS}}(1 / 13)$ genotypes.

The electrophoregrams of the overall sequenced sample were further scored by QSV analyser [22] to quantify the proportion of sequences containing $\mathrm{C}$ versus $\mathrm{T}(\mathrm{M}$ form $=\mathrm{T}$; $\mathrm{S}$-form $=\mathrm{C})$ or A versus $\mathrm{T}(\mathrm{M}$-form $=\mathrm{A} ; \mathrm{S}$ form $=\mathrm{T})$, based on relative peak heights at position $581\left(\mathrm{CNP}^{581}\right)$ and $690\left(\mathrm{CNP}^{690}\right)$, respectively. As expected based on the proximity of the IGS ${ }^{581}$ and IGS ${ }^{690}$ SNPs, the CNP scores were strongly correlated ( $\mathrm{r}$ $=0,97 \mathrm{p}<<0.001)$. The median CNP scores of the two SNPs were significantly different among the 7 IGS-types classified based on both IGS ${ }^{581}$ and IGS ${ }^{690}$ PCR-RFLPs $\left(\mathrm{IGS}^{581}: \mathrm{KW}-\mathrm{H}=116, \mathrm{p}<<0.001 ; \mathrm{IGS}^{690}: \mathrm{KW}-\mathrm{H}=109\right.$, $\mathrm{p}<<0.001$ ), with specimens identified as MM and SS by both PCR-RFLPs showing median CNP scores near 0.1 and 0.9 , respectively (as expected if one allele is fixed) and specimens identified as MS by both PCR-RFLPs showing intermediate scores (Figure 3). The heterozygotes $\left(\mathrm{MS}^{581}-\mathrm{MS}^{690}\right)$ were statistically different from the homozygotes (pairwise comparisons: $\mathrm{p}<0.001$; Additional file 1). Interestingly, specimens from Guinea Bissau and The Gambia, characterized by inconsistent PCR-RFLP patterns showed intermediate scores between those of $\mathrm{M}$ or $\mathrm{S}$ homozygotes $\left(\mathrm{MM}^{581}-\mathrm{MM}^{690}\right.$ or $\mathrm{SS}^{581}$. $\mathrm{SS}^{690}$ ) and MS heterozygotes $\left(\mathrm{MS}^{581}-\mathrm{MS}^{690}\right)$, suggesting that these specimens are characterized by an unequal number of copies of $\mathrm{M}$ - and S-arrays (pairwise comparisons: $\mathrm{p}>0.05$; Additional file 1). CNPs scores of individuals subdivided based on SINE-genotypes revealed that some SINE- $\mathrm{X}^{\mathrm{MM}}$ and SINE- $\mathrm{X}^{\mathrm{SS}}$ individuals are characterized by an unequal number of copies of $\mathrm{M}$ - and Sarrays [21]. It is relevant to note that the interpretation of single versus double peaks at the two IGS diagnostic sites determined either by eye inspection of chromatograms or by CNP score (i.e. SNP ${ }^{581}$ : homozygous $\mathrm{T}$, $\mathrm{CNP}<0.15$; homozygous $\mathrm{C}, \mathrm{CNP}>0.85$; $\mathrm{SNP}^{690}$ : 

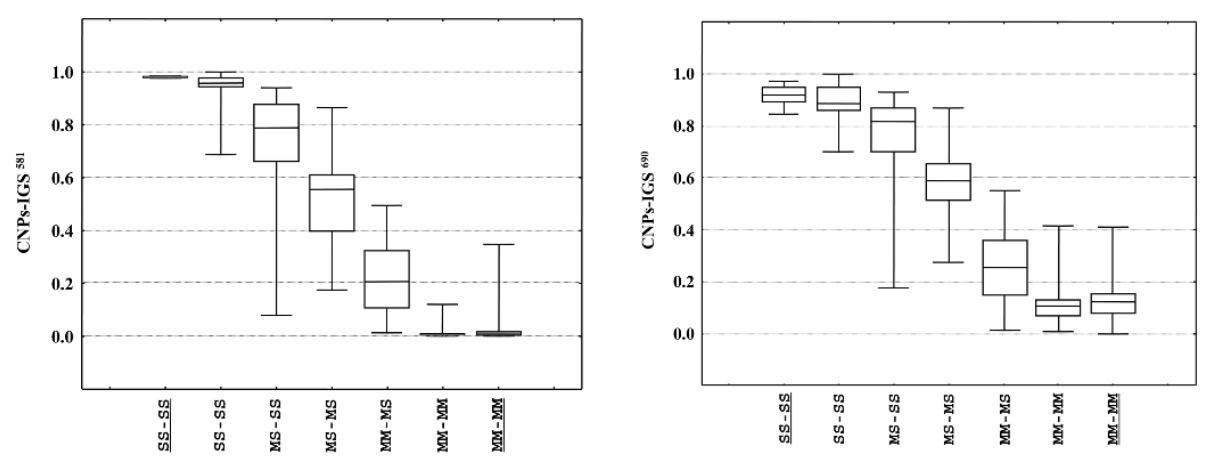

Figure 3 Box-plots of CNP scores of IGS ${ }^{581}$ SNP (a) and IGS ${ }^{690}$ SNP (b) in Anopheles gambiae specimens. Specimens are classified based on results from IGS $S^{581} / \mathrm{IGS}^{690}$ PCR-RFLPS. The underlined SS/SS $(N=9)$ and MM/MM $(N=15)$ groups correspond to S-form and M-form specimens from Burkina Faso and Angola, while the not-underlined groups correspond to specimens from The Gambia and Guinea Bissau (SSSS: $N=15$; MS-SS: $N=14$; MS-MS: $N=36$; MM-MS: $N=11$; MM-MM: $N=15$ ).

homozygous $\mathrm{A}, \mathrm{CNP}<0.18$; homozygous $\mathrm{T}, \mathrm{CNP}>$ 0.85 ) were consistent in $97 \%$ of the cases. IMP-PCR confirmed the results from sequencing, with the exception of $2 \mathrm{~S}$-form individuals from The Gambia genotyped as MS by both IMP-PCR and AS-PCR.

Sequence analysis also showed that all samples were homozygotes $(\mathrm{G})$ at position IGS ${ }^{580}$, where Favia et al [13] reported an addtional form-specific SNP (M-form = G; S-form $=\mathrm{A}$ ). Moreover, alignment of IGS amplicon from sequenced individuals from Guinea Bissau (Mform: $\mathrm{N}=31$; S-form: $\mathrm{N}=32$ ), showed 4 IGS-polymorphic sites in addition to IGS ${ }^{581}$ and IGS ${ }^{690}$ : i) site IGS $^{485}$ was found heterozygous $(\mathrm{C} / \mathrm{T})$ in one M/S specimen; ii) site IGS ${ }^{489}$ was found heterozygous (G/A) in 2 $\mathrm{M}$ and in $1 \mathrm{M} / \mathrm{S}$ specimens; iii) site IGS $^{491}$ was found homozygous $(\mathrm{T})$ in one $\mathrm{M}$ specimen and heterozygous $(\mathrm{T} / \mathrm{C})$ in $2 \mathrm{M} / \mathrm{S}$ specimens. Finally, a A/G polymorphism at site IGS ${ }^{612}$ was found in linkage with both IGS $^{581}$ and IGS $^{690}$ diagnostic sites, as already reported by Oliveira et al [20].

\section{Discussion}

Since their description 10 years ago [5], A. gambiae M and $\mathrm{S}$ molecular forms have been the focus of extensive field studies aimed to evaluate their macro- and microgeographic distribution and to analyse their population genetics, their relative role as malaria vectors and their resistance to insecticides used in malaria vector control campaigns. All these studies have exploited different approaches for $\mathrm{M}$ and $\mathrm{S}$ identification - based on either direct PCR-amplification of form-specific bands by allele-specific primers designed in the same region (ASPCR, cited in 17 out of 56 papers since 2006, see Additional file 2) or the restriction of form-specific SNPs in the IGS rDNA region (IGS ${ }^{581}$ and IGS $^{690}$ PCR-RFLPs: cited in [24] and [2], respectively, Additional file 2). In most of these papers only a single identification approach was used, while in four of them both AS-PCR and PCR-RFLP ${ }^{581}$ methods were applied. Moreover, a few authors (nine papers; Additional file 2) still exploited the original approach developed by Favia et al [15], which is based on the same restriction site of Fanello et al [16], but requires the pre-identification of A. gambiae s.s. specimens. Overall, so far, the general attitude has been to consider all these approaches fully interchangeable; however, recent data from the westernmost extreme of $M$ and $S$ range (i.e. The Gambia and Guinea Bissau [21]) have highlighted that this assumption is not correct. The results here presented confirm this conclusion and allow to pinpoint the bases of the observed inconsistencies among results of the three approaches, as follows.

\section{Incorrect match of $\mathrm{M}$ and $\mathrm{S}$ specific primers used in the AS-PCR approach}

A higher number of MS heterozygous patterns resulted from AS-PCR than from PCR-RFLP genotyping, mostly in specimens from Burkina Faso, Guinea Bissau and The Gambia. This is due to a low specificity of the AS-PCR approach (using form-specific primers differing only for the SNP variant at 3' end) which is affected by the inability of this single 3' mismatch to prevent extension of the non-specific primer by the polymerase [23]. In fact, this low specificity has been recently circumvented using primers containing an additional intentional mismatch at the third nucleotide from the 3' end which increases the power of $T a q$ polymerase to extend from the 'right' primer and to partly optimize the reaction thermodynamics when both primers anneal on the template, thus providing more power to identify MS hybrids (IMP-PCR [14]). The comparison between the results of the AS-PCR and of IMP-PCR highlighted a higher specificity of the latter. In fact, IMP-PCR produced patterns consistent with those obtained either by sequencing or 
by the two PCR-RFLP approaches in all specimens tested $(\mathrm{N}=146)$, with the exception of two S-form specimens from Gambia genotyped as MS by IMP-PCR (Table 2, line 18).

\section{Presence of polymorphisms in the recognition sequence} of restriction enzymes used in the PCR-RFLP approaches

An A/C heterozygous pattern was observed in the recognition sequence of the enzyme utilised in IGS ${ }^{690}$ PCR-RFLP (i.e. MseI) in five out of $32 \mathrm{M}$-form specimens from Angola. This polymorphism did not allow the complete cleavage of the M-specific PCR-amplified band, thus producing a false heterozygous $\mathrm{MS}^{690}$ pattern.

\section{Incomplete cleavage during the restriction reaction} A few specimens from Burkina Faso, Cameroon, Guinea Bissau and The Gambia were incorrectly genotyped as MS by PCR-RFLP $\left(\mathrm{IGS}^{581}: \mathrm{N}=8 ; \mathrm{IGS}^{690}: \mathrm{N}=5\right.$ ), due to incomplete digestion of the PCR-amplified fragment during restriction. A second round of PCR-RFLP reactions did not change the observed PCR-pattern and the specimens were confirmed to be homozygous at each site by sequencing.

\section{Presence of different number of copies of $\mathrm{M}$ and S- specific IGS-arrays in single individuals}

This has been already hypothesized by Caputo et al [21] based on the inconsistent results from PCR-RFLP ${ }^{581}$ and SINE-PCR on samples from Guinea Bissau and The Gambia, where a secondary contact zone between the two molecular forms has been hypothesized based on the high frequencies of MS putative hybrids reported $[19,20]$. The results obtained confirm this hypothesis and highlight the technical bias which emerged when the same samples were identified by PCR-RFLP ${ }^{690}$. In fact, the restriction enzyme used for the PCR-RFLP ${ }^{581}$ (i.e. HhaI) recognizes a S-specific restriction site, while the enzyme used for the PCR-RFLP ${ }^{690}$ (i.e MseI) recognizes a $\mathrm{M}$-specific restriction site. It is possible to hypothesize that the PCR-amplification of individuals characterized by a number of copies of the M-IGS type higher than of S-IGS type exponentially increases this difference, producing a strong $\mathrm{M}^{581}$ band and a weak $S^{581}$ one. The latter may not be visible on the agarose gel after the restriction step resulting in a $\mathrm{MM}^{581} / \mathrm{MS}^{690}$ RFLP pattern. Conversely, individuals characterized by a number of copies of the S-IGS type higher than of MIGS type are likely to produce a MS ${ }^{581} / \mathrm{SS}^{690}$ RFLP pattern. This hypothesis is further supported by the relative high frequency of $\mathrm{MM}^{581} / \mathrm{MS}^{690}$ (9\%) and $\mathrm{MS}^{581} / \mathrm{SS}^{690}$ (12\%) specimens in the sample analysed, and by the absence of $\mathrm{SS}^{581} / \mathrm{MS}^{690}$ and $\mathrm{MS}^{581} / \mathrm{MM}^{690}$ genotypes. The QSV analysis of IGS sequences confirms that
$\mathrm{MM}^{581} / \mathrm{MS}^{690}$ or $\mathrm{MS}^{581} / \mathrm{SS}^{690}$ individuals have proportions of array copy number intermediate between those of either $\mathrm{MM}^{581} / \mathrm{MM}^{690}$ and $\mathrm{MS}^{581} / \mathrm{MS}^{690}$ or $\mathrm{SS}^{581} /$ $\mathrm{SS}^{690}$ and $\mathrm{MS}^{581} / \mathrm{MS}^{690}$ individuals, respectively (Table 2).

The comparison between the results of the IGS-genotyping (including direct sequencing, in case of inconsistencies among the approaches utilized) and of SINEPCR showed consistent identifications in all samples, with the exception of those from Guinea Bissau and The Gambia. In these populations mismatches were observed, mostly due to SS and MM SINE-homozygotes with a heterozygous $\mathrm{MS}^{\mathrm{IGS}}$ genotype or, less frequently, to MS SINE-heterozygotes with $\mathrm{MM}^{\mathrm{IGS}}$ and $\mathrm{SS}^{\mathrm{IGS}}$ genotypes, while no opposite MM-SINE/SS ${ }^{\mathrm{IGS}}$ or SS-SINE/ $\mathrm{MM}^{\mathrm{IGS}}$ were found. As discussed in Caputo et al [21], the former individuals are likely to represent Fn progenies of inter-form crosses occurring in this "secondary contact zone", where the reproductive isolation mechanisms between $\mathrm{M}$ - and S-forms appear to be less effective than in the rest of the molecular forms sympatric distribution range. In fact, discrepancies between results from PCR-RFLP ${ }^{581}$ and SINE-PCR led to hypothesize that the high frequencies of $\mathrm{MS}^{581}$ patterns found in Guinea Bissau and in The Gambia were due to the presence of both $\mathrm{M}$ - and $\mathrm{S}$-arrays in the multi-copy IGS rDNA region of single individuals, suggesting inter-locus recombination [21]. In this scenario, the SINE-PCR genotyping allows to discriminate putative MS hybrids from progenies of Fn-backcrosses (i.e. MM or SS SINE-homozygotes showing both M- and S-specific IGS arrays). In fact, the SINE-PCR genotyping of four MS ${ }^{581}$ specimens reported in della Torre et al [7] (from Benin, Mali, Guinea and The Gambia) confirmed their putative hybrid origins.

On the other hand, the finding of high frequencies of consistent MS IGS/SINE patterns in larval samples from Burkina Faso, led Riehle et al. [24] to carry out a deeper genetic characterization of these individuals and to hypothesize that they may represent a new A. gambiae "sub-form" highly differentiated from $\mathrm{M}$ and $\mathrm{S}$. This "sub-form" seems to be also characterized by a MS SINE-polymorphism in Hardy-Weinberg equilibrium consistent with IGS-patterns, a very unexpected scenario which needs to be taken into consideration when speculating on the origin of this putative "sub-form". In fact, based on their evolutionary dynamics, both IGS and SINE markers are expected to undergo rapid fixation in a randomly mated diverging taxa rather than being found at equilibrium in a taxon separated from $\mathrm{M}$ - and S-form.

Overall, the results here presented, as well as those by Riehle et al [24], do not only highlight limits in the approaches currently applied to discriminate M- and S- 
forms, but also on the actual definition of the two molecular forms, which might not fully correspond to the two A. gambiae incipient species in their entire geographical range. The $M$ and $S$ molecular forms are, in fact, defined specifically based on SNPs in the IGS region, which were initially used to discriminate between Mopti and Savanna/Bamako chromosomal forms in Mali and Burkina Faso [15] and, later, to identify two incipient species in other geographical regions, where the correlation with specific karyotypes was more complex $[1,5,7,25]$. Since their initial description, all data on the genetic, ecological and behavioural divergence of $\mathrm{M}$ and $\mathrm{S}$ forms were obtained based on the IGS diagnostics, leading to a general acceptance of the IGS-SNPs as form-specific characters possibly linked to genes or genomic regions instrumental to the speciation process. This view was reinforced by the fact that the IGS lies within X-chromosome centromeric region, where most genetic divergence between $\mathrm{M}$ - and S-forms is observed $[11,12,25,26]$ and by the consistent almost complete absence of MS ${ }^{\mathrm{IGS}}$ genotypes in nature. The finding of different number of copies of $\mathrm{M}$ - and S- IGS-arrays in single individuals from the western extreme of the molecular form range [21] highlighted how the genetic definition of the two A. gambiae incipient species is not fully tenable along their entire range. The recent sequencing of the genome of $\mathrm{M}$ - and $\mathrm{S}$-colonies from Mali [11] and the availability of affordable SNP microarray platforms [12], will probably allow in the near future a relatively easy processing of $A$. gambiae populations from the entire range. Moreover, the likely detection of multiple markers along their $\mathrm{M}$-and $\mathrm{S}$-form genome and their association will possibly allow a more precise definition of the two incipient species, as in the case of the allelic variant of TEP1 immune gene found to be fixed in $\mathrm{M}$ samples from Mali and Burkina Faso but absent in sympatric $S$ populations [27].

\section{Conclusion}

The results obtained reveal that the PCR and PCR-RFLP approaches most commonly utilized to identify A. gambiae molecular forms are not fully interchangeable, as usually assumed. Different kinds of technical biases have been highlighted, which may result in an overestimation of MS putative hybrids. This is particularly relevant in settings of realised gene flow between molecular forms, such as the areas at the extreme West African distribution of $A$. gambiae. Moreover, the IMP-PCR developed by Wilkins et al [14], and so far applied almost exclusively on laboratory samples, was shown to be more specific than AS-PCR thus encouraging its exploitation in large scale screenings of field A. gambiae samples. However, the risk of biases due to local polymorphisms in the annealing sequences should be always be taken into consideration.

From an operational perspective, it needs to be highlighted that the choice of the most convenient method for large-scale $\mathrm{M}$ - and S-form identification, also depends from technical considerations (e.g. laboriousness of the different approaches) and from the sympatric presence of other members of the A. gambiae complex in the study area. In fact, only IGS ${ }^{581}$ PCR-RFLP allows the simultaneous identification of all species and molecular forms and could be the method of choice whenever the presence of other A. gambiae complex members (i.e. Anopheles melas, Anopheles merus, Anopheles quadriannulatus and/or Anopheles bwambae) cannot be excluded. Alternatively, the IMP-PCR approach could be used after A. gambiae s.s. specimens are identified by the species-specific PCR developed by Scott et al [28], thus avoiding the risks connected to the restriction step in IGS ${ }^{581}$ PCR-RFLP. The choice of one or the other approach should also be linked to the relative frequencies of $A$. gambiae s.s. in the sample (i.e. if this frequency is low, the species-specific PCR + IMPPCR approach could be more convenient, as only few specimens would require to be identified by IMP-PCR; if high, the IGS ${ }^{581}$ PCR-RFLP could be a more straightforward approach). It should be noted that the IGS ${ }^{690}$ PCR-RFLP is more sensitive in cases of degraded DNA samples and that it could simultaneously identify Mand S-forms and A. arabiensis [17]. On the other hand, the use of AS-PCR would require preliminary identification of A. gambiae s.s. specimens and is shown to be subject to more biases than the other approaches. The PCR-RFLP originally developed by Favia et al [15] and still recently utilized by some authors (see Additional file 2) is comparatively less suitable for large-scale studies as it requires previous complex species identification and yet it targets the same SNP as the PCRRFLP $^{581}$. The latter method is more efficient since it allows for simultaneous species and molecular form identification on a much smaller amplicon (367 bp compared to $1.3 \mathrm{~kb}[15])$.

It is also proposed that, due to the straightforward amplification of small DNA fragments (i.e. 249 and 479 bp for S- and M-forms, respectively), SINE-PCR could be conveniently applied to easily identify $\mathrm{M}$ - and Sforms (even without preliminary species-specific PCR identification in areas where exclusive sympatry with $A$. arabiensis is found). However, it is important to keep in mind that the M-form specific SINE insertion is a character linked to the IGS-SNPs defining the M- and Sforms along most of their range, but with a different evolutionary history (i.e. its origin and rapid fixation in M-form). 
Finally, it is recommend to apply more than one genotyping approach (and/or sequencing of the IGS-amplicon) when identifying samples from previously unexplored geographic areas within $\mathrm{M}$ - and S-form sympatric range and whenever MS hybrid patterns are observed (Additional file 3). In this latter case, in fact, presence of both M- and S-specific IGS arrays in single individuals could lead to a misleading calculation of frequency of hybridization between $\mathrm{M}$ and $\mathrm{S}$ forms, as shown in populations from Guinea Bissau and The Gambia, where the simultaneous use of SINE-PCR allowed a better understanding of the local situation.

\section{Additional material}

Additional file 1: $\mathrm{P}$ values of pairwise comparisons of $\mathrm{CNP}^{581}$ and

CNP $^{690}$ scores The data show $\mathrm{P}$ values of pairwise comparisons of

CNP ${ }^{581}$ and $C N P^{690}$ scores calculated by QSV analyser in Anopheles gambiae specimens classified by IGS ${ }^{581} / \mathrm{IGS}^{690}$ PCR-RFLPs.

Additional file 2: Papers on Anopheles gambiae $\mathrm{M}$ and $\mathrm{S}$ molecular forms published since 2006 [2-4,9,13,15-17,19,20,24,25,32-70]. Papers focused on Anopheles gambiae M and S molecular forms are listed to highlight the identification methods mostly utilized in the last five years.

Additional file 3: Frequency of $\mathrm{M}$ and $\mathrm{S}$ molecular forms and putative MS hybrids in 10/56 papers on Anopheles gambiae s.s. published since 2006

\begin{abstract}
Abbreviations
IGS $^{581}$ SNP: T/C Single Nucleotide Polymorphism at position 581 of IGS rDNA region; IGS ${ }^{690}$ SNP: A/T Single Nucleotide Polymorphism at position 690 of IGS rDNA region; PCR-RFLP ${ }^{581}$ : PCR-RFLP recognising IGS ${ }^{581}$ SNP; PCR-RFLP ${ }^{690}$ : PCR-RFLP recognising IGS $S^{690}$ SNP; AS-PCR: PCR based on Allele-Specific primers designed on IGS ${ }^{581}$ SNP; SINE-PCR: PCR approach based on the specific and irreversible single-locus insertion of a Short Interspersed Transposable Element in the X-chromosome centromeric region; IMP-PCR: PCR based on Intentional Mismatch Primers annealing on IGS $^{581}$ and IGS ${ }^{690}$ SNPs; CNP ${ }^{581}$ : Copy Number Proportion of T/C alleles at positions 581 in the IGS amplicon; CNP ${ }^{690}$ : Copy Number Proportion of A/T alleles at positions 690 in the IGS amplicon; $\mathbf{M M}^{\mathbf{5 8 1}}, \mathbf{S S}^{581}, \mathbf{M S}^{581}$ : M- and Sform specific genotypes at IGS ${ }^{581}$ SNP; $\mathbf{M M}^{690}, \mathrm{SS}^{690}, \mathbf{M S}^{690}$ : M- and S-form specific genotypes at IGS ${ }^{690}$ SNP; MM-SINE, SS-SINE, MS-SINE: M- and Sform specific SINE genotypes.
\end{abstract}

\section{Acknowledgements and funding}

We are grateful to all scientists and entomology teams who provided samples utilized in this study; we especially thank: K. Adasi, T. Baldet, G. Carrara, P.J. Cani, D.J. Conway, C. Curtis, F. Fortes, M. Jawara, T.G.T. Jaenson, A. Mendjibe, D.C. Nwakanma, K. Palsson and Y.T. Touré. The project was supported by INFRAVEC project (FP7-INFRASTRUCTURES-2008: Grant Agreement Number 228421) and by SAPIENZA University (Progetto Ateneo 2009). FS was partially supported by Compagnia di San Paolo (Torino, Italy) in the context of and C.I.R.M. - Italian Malaria Network. BC was partially supported by I Faculty of Medicine, SAPIENZA University; EM was supported by "Ateneo Federato delle Scienze delle Politiche Pubbliche e Sanitarie" (SAPIENZA University) and C.I.R.M. - Italian Malaria Network.

\section{Author details}

${ }^{1}$ Istituto Pasteur-Fondazione Cenci-Bolognetti, Dipartimento di Sanità Pubblica e Malattie Infettive, Università SAPIENZA, Piazzale Aldo Moro 5, 00185, Rome, Italy. UEl Parasitologia Médica, Centro de Malária e outras Doenças Tropicais, Instituto de Higiene e Medicina Tropical, Universidade Nova de Lisboa, Rua da Junqueira, 100, 1349-008 Lisbon, Portugal. ${ }^{3}$ Istituto
Pasteur-Fondazione Cenci-Bolognetti, Dipartimento di Biologia e Biotecnologie, Università SAPIENZA, Piazzale Aldo Moro 5, 00185, Rome, Italy.

\section{Authors' contributions}

FS, MC and JLV carried out the molecular genotyping and participated in the sequence alignment. FS, BC and EM performed the statistical analyses. VP and JP participated in the design of the study and contributed to data analyses. AdT conceived of the study, participated in its design and coordination, and drafted the manuscript. FS, BC, MC, EM, VP and JP contributed to the manuscript finalization. All authors read and approved the final manuscript.

\section{Competing interests}

The authors declare that they have no competing interests.

Received: 14 June 2011 Accepted: 2 August 2011

Published: 2 August 2011

\section{References}

1. della Torre A, Costantini C, Besansky NJ, Caccone A, Petrarca V, Powell JR, Coluzzi M: Speciation within Anopheles gambiae-the glass is half full. Science 2002, 298:115-117.

2. Costantini C, Ayala D, Guelbeogo WM, Pombi M, Some CY, Bassole $\mathbb{H}$, Ose K, Fotsing JM, Sagnon N, Fontenille D, Besansky NJ, Simard F: Living at the edge: biogeographic patterns of habitat segregation conform to speciation by niche expansion in Anopheles gambiae. BMC Ecol 2009, 9:16.

3. Simard F, Ayala D, Kamdem GC, Pombi M, Etouna J, Ose K, Fotsing JM, Fontenille D, Besansky NJ, Costantini C: Ecological niche partitioning between Anopheles gambiae molecular forms in Cameroon: the ecological side of speciation. BMC Ecol 2009, 9:17.

4. White BJ, Cheng C, Simard F, Costantini C, Besansky NJ: Genetic association of physically unlinked islands of genomic divergence in incipient species of Anopheles gambiae. Mol Ecol 2010, 19:925-939.

5. della Torre A, Fanello C, Akogbeto M, Dossou-yovo J, Favia G, Petrarca V, Coluzzi M: Molecular evidence of incipient speciation within Anopheles gambiae s.s. in West Africa. Insect Mol Biol 2001, 10:9-18.

6. Gentile G, Slotman M, Ketmaier V, Powell JR, Caccone A: Attempts to molecularly distinguish cryptic taxa in Anopheles gambiae s.s. Insect Mol Biol 2001, 10:25-32

7. della Torre A, Tu Z, Petrarca V: On the distribution and genetic differentiation of Anopheles gambiae s.s. molecular forms. Insect Biochem Mol Biol 2005, 35:755-769

8. Lehmann T, Diabate A: The molecular forms of Anopheles gambiae: a phenotypic perspective. Infect Genet Evol 2008, 8:737-746.

9. Djogbenou L, Dabire R, Diabate A, Kengne P, Akogbeto M, Hougard JM, Chandre F: Identification and geographic distribution of the ACE-1R mutation in the malaria vector Anopheles gambiae in south-western Burkina Faso, West Africa. Am J Trop Med Hyg 2008, 78:298-302.

10. Santolamazza F, Calzetta M, Etang J, Barrese E, Dia I, Caccone A, Donnelly MJ, Petrarca V, Simard F, Pinto J, della Torre A: Distribution of knock-down resistance mutations in Anopheles gambiae molecular forms in west and west-central Africa. Malar J 2008, 7:74.

11. Lawniczak MK, Emrich SJ, Holloway AK, Regier AP, Olson M, White B, Redmond S, Fulton L, Appelbaum E, Godfrey J, Farmer C, Chinwalla A Yang SP, Minx P, Nelson J, Kyung K, Walenz BP, Garcia-Hernandez E, Aguiar M, Viswanathan LD, Rogers YH, Strausberg RL, Saski CA, Lawson D, Collins FH, Kafatos FC, Christophides GK, Clifton SW, Kirkness EF, Besansky NJ: Widespread divergence between incipient Anopheles gambiae species revealed by whole genome sequences. Science 2011 330:512-514

12. Neafsey DE, Lawniczak MK, Park DJ, Redmond SN, Coulibaly MB, Traore SF, Sagnon N, Costantini C, Johnson C, Wiegand RC, Collins FH, Lander ES, Wirth DF, Kafatos FC, Besansky NJ, Christophides GK, Muskavitch MA: SNP genotyping defines complex gene-flow boundaries among African malaria vector mosquitoes. Science 2011, 330:514-517.

13. Favia G, Lanfrancotti A, Spanos L, Siden-Kiamos I, Louis C: Molecular characterization of ribosomal DNA polymorphisms discriminating among chromosomal forms of Anopheles gambiae s.s. Insect Mol Biol 2001, 10:19-23. 
14. Wilkins EE, Howell PI, Benedict MQ: IMP PCR primers detect single nucleotide polymorphisms for Anopheles gambiae species identification, Mopti and Savanna rDNA types, and resistance to dieldrin in Anopheles arabiensis. Malar J 2006, 5:125.

15. Favia G, della Torre A, Bagayoko M, Lanfrancotti A, Sagnon N, Toure YT, Coluzzi M: Molecular identification of sympatric chromosomal forms of Anopheles gambiae and further evidence of their reproductive isolation. Insect Mol Biol 1997, 6:377-383.

16. Fanello C, Santolamazza F, della Torre A: Simultaneous identification of species and molecular forms of the Anopheles gambiae complex by PCRRFLP. Med Vet Entomol 2002, 16:461-464.

17. Santolamazza F, della Torre A, Caccone A: Short report: A new polymerase chain reaction-restriction fragment length polymorphism method to identify Anopheles arabiensis from An. gambiae and its two molecular forms from degraded DNA templates or museum samples. Am J Trop Med Hyg 2004, 70:604-606.

18. Santolamazza F, Mancini E, Simard F, Qi Y, Tu Z, della Torre A: Insertion polymorphisms of SINE200 retrotransposons within speciation islands of Anopheles gambiae molecular forms. Malar J 2008, 7:163.

19. Caputo B, Nwakanma D, Jawara M, Adiamoh M, Dia I, Konate L, Petrarca V, Conway DJ, della Torre A: Anopheles gambiae complex along The Gambia river, with particular reference to the molecular forms of An. gambiae s. s. Malar J 2008, 7:182.

20. Oliveira E, Salgueiro P, Palsson K, Vicente $J$, Arez AP, Jaenson TG, Caccone A, Pinto J: High levels of hybridization between molecular forms of Anopheles gambiae from Guinea Bissau. J Med Entomol 2008, 45:1057-1063.

21. Caputo B, Santolamazza F, Vicente JL, Nwakanma DC, Jawara M, Palsson K, Jaenson T, White BJ, Mancini E, Petrarca V, Conway DJ, Besansky NJ, Pinto J, della Torre A: The "Far-West" of Anopheles gambiae Molecular Forms. PLoS One 2011, 6:e16415.

22. Carr IM, Robinson Jl, Dimitriou R, Markham AF, Morgan AW, Bonthron DT: Inferring relative proportions of DNA variants from sequencing electropherograms. Bioinformatics 2009, 25:3244-3250.

23. Black WCt, Vontas JG: Affordable assays for genotyping single nucleotide polymorphisms in insects. Insect Mol Biol 2007, 16:377-387.

24. Riehle MM, Guelbeogo WM, Gneme A, Eiglmeier K, Holm I, Bischoff E, Garnier T, Snyder GM, Li X, Markianos K, Sagnon N, Vernick KD: A cryptic subgroup of Anopheles gambiae is highly susceptible to human malaria parasites. Science 2011, 331:596-598.

25. Turner TL, Hahn MW, Nuzhdin SV: Genomic islands of speciation in Anopheles gambiae. PLoS Biol 2005, 3:e285.

26. Stump AD, Fitzpatrick MC, Lobo NF, Traore S, Sagnon N, Costantini C, Collins FH, Besansky NJ: Centromere-proximal differentiation and speciation in Anopheles gambiae. Proc Natl Acad Sci USA 2005, 102:15930-15935.

27. White BJ, Lawniczak MK, Cheng C, Coulibaly MB, Wilson MD, Sagnon N, Costantini C, Simard F, Christophides GK, Besansky NJ: Adaptive divergence between incipient species of Anopheles gambiae increases resistance to Plasmodium. Proc Natl Acad Sci USA 2011, 108:244-249.

28. Scott JA, Brogdon WG, Collins FH: Identification of single specimens of the Anopheles gambiae complex by the polymerase chain reaction. Am J Trop Med Hyg 1993, 49:520-529.

29. Gentile G, Della Torre A, Maegga B, Powell JR, Caccone A: Genetic differentiation in the African malaria vector, Anopheles gambiae s.S., and the problem of taxonomic status. Genetics 2002, 161:1561-1578.

30. Calzetta M, Santolamazza F, Carrara GC, Cani PJ, Fortes F, Di Deco MA, della Torre A, Petrarca V: Distribution and chromosomal characterization of the Anopheles gambiae complex in Angola. Am J Trop Med Hyg 2008, 78:169-175.

31. Kristan M, Fleischmann H, della Torre A, Stich A, Curtis CF: Pyrethroid resistance/susceptibility and differential urban/rural distribution of Anopheles arabiensis and An. gambiae s.s. malaria vectors in Nigeria and Ghana. Med Vet Entomol 2003, 17:326-332.

32. Anges $Y$, Thibaud M, Gil $P$, Fabrice $C$, Alex A, Luc D, Roch D, Rock A, Michel $B$, Isabelle G, Martin A: Cotton pest management practices and the selection of pyrethroid resistance in Anopheles gambiae population in Northern Benin. Parasit Vectors 2011, 4:60

33. Awolola TS, Oduola AO, Oyewole IO, Obansa JB, Amajoh CN, Koekemoer LL, Coetzee M: Dynamics of knockdown pyrethroid insecticide resistance alleles in a field population of Anopheles gambiae s.s. in southwestern Nigeria. J Vector Borne Dis 2007, 44:181-188.

34. Awolola TS, Oyewole IO, Amajoh CN, Idowu ET, Ajayi MB, Oduola A, Manafa OU, Ibrahim K, Koekemoer LL, Coetzee M: Distribution of the molecular forms of Anopheles gambiae and pyrethroid knock down resistance gene in Nigeria. Acta Trop 2005, 95:204-209.

35. Dery DB, Brown C, Asante KP, Adams M, Dosoo D, Amenga-Etego S, Wilson M, Chandramohan D, Greenwood B, Owusu-Agyei S: Patterns and seasonality of malaria transmission in the forest-savannah transitional zones of Ghana. Malar J 2010, 9:314.

36. Djogbenou L, Pasteur N, Bio-Bangana S, Baldet T, Irish SR, Akogbeto M, Weill M, Chandre F: Malaria vectors in the Republic of Benin: distribution of species and molecular forms of the Anopheles gambiae complex. Acta Trop 2010, 114:116-122.

37. Koekemoer LL, Spillings BL, Christian RN, Lo TC, Kaiser ML, Norton RA, Oliver SV, Choi KS, Brooke BD, Hunt RH, Coetzee M: Multiple Insecticide Resistance in Anopheles gambiae (Diptera: Culicidae) from Pointe Noire, Republic of the Congo. Vector Borne Zoonotic Dis 2011, 0:1-8.

38. Tripet F, Dolo G, Lanzaro GC: Multilevel analyses of genetic differentiation in Anopheles gambiae s.s. reveal patterns of gene flow important for malaria-fighting mosquito projects. Genetics 2005, 169:313-324.

39. Vezenegho SB, Brooke BD, Hunt RH, Coetzee M, Koekemoer LL: Malaria vector composition and insecticide susceptibility status in Guinea Conakry, West Africa. Med Vet Entomol 2009, 23:326-334

40. Yadouleton AW, Padonou G, Asidi A, Moiroux N, Bio-Banganna S, Corbel V, N'Guessan R, Gbenou D, Yacoubou I, Gazard K, Akogbeto MC: Insecticide resistance status in Anopheles gambiae in southern Benin. Malar J 2010 9:83.

41. Boulesteix M, Simard F, Antonio-Nkondjio C, Awono-Ambene HP, Fontenille D, Biemont C: Insertion polymorphism of transposable elements and population structure of Anopheles gambiae $\mathrm{M}$ and S molecular forms in Cameroon. Mol Ecol 2007, 16:441-452

42. Sharp BL, Ridl FC, Govender D, Kuklinski J, Kleinschmidt I: Malaria vector control by indoor residual insecticide spraying on the tropical island of Bioko, Equatorial Guinea. Malar J 2007, 6:52.

43. Tchuinkam T, Simard F, Lele-Defo E, Tene-Fossog B, Tateng-Ngouateu A Antonio-Nkondjio C, Mpoame M, Toto JC, Njine T, Fontenille, AwonoAmbene HP: Bionomics of Anopheline species and malaria transmission dynamics along an altitudinal transect in Western Cameroon. BMC Infect Dis 2010, 10:119.

44. Tripet F, Wright J, Cornel A, Fofana A, McAbee R, Meneses C, Reimer L, Slotman M, Thiemann T, Dolo G, Traore S, Lanzaro G: Longitudinal survey of knockdown resistance to pyrethroid (kdr) in Mali, West Africa, and evidence of its emergence in the Bamako form of Anopheles gambiae s. s. Am J Trop Med Hyg 2007, 76:81-87.

45. Tanga MC, Ngundu Wl: Ecological transition from natural forest to tea plantations: effect on the dynamics of malaria vectors in the highlands of Cameroon. Trans R Soc Trop Med Hyg 2010, 104:659-668.

46. Mourou JR, Coffinet T, Jarjaval F, Pradines B, Amalvict R, Rogier C, Kombila M, Pages F: Malaria transmission and insecticide resistance of Anopheles gambiae in Libreville and Port-Gentil, Gabon. Malar J 2010, 9:321.

47. Horton AA, Lee Y, Coulibaly CA, Rashbrook VK, Cornel AJ, Lanzaro GC, Luckhart S: Identification of three single nucleotide polymorphisms in Anopheles gambiae immune signaling genes that are associated with natural Plasmodium falciparum infection. Malar J 2010, 9:160.

48. Aguilar R, Simard F, Kamdem C, Shields T, Glass GE, Garver LS, Dimopoulos G: Genome-wide analysis of transcriptomic divergence between laboratory colony and field Anopheles gambiae mosquitoes of the $\mathrm{M}$ and S molecular forms. Insect Mol Biol 2010, 19:695-705.

49. Ranson $\mathrm{H}$, Abdallah $\mathrm{H}$, Badolo A, Guelbeogo WM, Kerah-Hinzoumbe C, Yangalbe-Kalnone E, Sagnon N, Simard F, Coetzee M: Insecticide resistance in Anopheles gambiae: data from the first year of a multi-country study highlight the extent of the problem. Malar J 2009, 8:299.

50. Nwane P, Etang J, Chouaibou M, Toto JC, Kerah-Hinzoumbe C, Mimpfoundi R, Awono-Ambene HP, Simard F: Trends in DDT and pyrethroid resistance in Anopheles gambiae s.s. populations from urban and agro-industrial settings in southern Cameroon. BMC Infect Dis 2009, 9:163

51. Lee Y, Cornel AJ, Meneses CR, Fofana A, Andrianarivo AG, McAbee RD, Fondjo E, Traore SF, Lanzaro GC: Ecological and genetic relationships of 
the Forest-M form among chromosomal and molecular forms of the malaria vector Anopheles gambiae sensu stricto. Malar J 2009, 8:75.

52. Etang J, Vicente JL, Nwane P, Chouaibou M, Morlais I, Do Rosario VE, Simard F, Awono-Ambene P, Toto JC, Pinto J: Polymorphism of intron-1 in the voltage-gated sodium channel gene of Anopheles gambiae s.s. populations from Cameroon with emphasis on insecticide knockdown resistance mutations. Mol Ecol 2009, 18:3076-3086.

53. Diabate A, Dao A, Yaro AS, Adamou A, Gonzalez R, Manoukis NC, Traore SF, Gwadz RW, Lehmann T: Spatial swarm segregation and reproductive isolation between the molecular forms of Anopheles gambiae. Proc Biol Sci 2009, 276:4215-4222.

54. Ridl FC, Bass C, Torrez M, Govender D, Ramdeen V, Yellot L, Edu AE, Schwabe C, Mohloai P, Maharaj R, Kleinschmidt I: A pre-intervention study of malaria vector abundance in Rio Muni, Equatorial Guinea: their role in malaria transmission and the incidence of insecticide resistance alleles. Malar J 2008, 7:194.

55. Reimer L, Fondjo E, Patchoke S, Diallo B, Lee Y, Ng A, Ndjemai HM, Atangana J, Traore SF, Lanzaro G, Cornel AJ: Relationship between kdr mutation and resistance to pyrethroid and DDT insecticides in natural populations of Anopheles gambiae. J Med Entomol 2008, 45:260-266.

56. Diabate A, Dabire RK, Heidenberger K, Crawford J, Lamp WO, Culler LE, Lehmann T: Evidence for divergent selection between the molecular forms of Anopheles gambiae: role of predation. BMC Evol Biol 2008, 8:5.

57. Turner TL, Hahn MW: Locus- and population-specific selection and differentiation between incipient species of Anopheles gambiae. Mol Biol Evol 2007, 24:2132-2138.

58. Slotman MA, Tripet F, Cornel AJ, Meneses CR, Lee $Y$, Reimer $L$, Thiemann TC, Fondjo E, Fofana A, Traore SF, Lanzaro GC: Evidence for subdivision within the M molecular form of Anopheles gambiae. Mol Ecol 2007, 16:639-649.

59. Coulibaly MB, Pombi M, Caputo B, Nwakanma D, Jawara M, Konate L, Dia I, Fofana A, Kern M, Simard F, Conway DJ, Petrarca V, della Torre A, Traore S, Besansky NJ: PCR-based karyotyping of Anopheles gambiae inversion 2Rj identifies the BAMAKO chromosomal form. Malar J 2007, 6:133.

60. Caputo B, Dani FR, Horne GL, N'Fale S, Diabate A, Turillazzi S, Coluzzi M, Costantini C, Priestman AA, Petrarca V, della Torre A: Comparative analysis of epicuticular lipid profiles of sympatric and allopatric field populations of Anopheles gambiae s.s. molecular forms and An. arabiensis from Burkina Faso (West Africa). Insect Biochem Mol Biol 2007, 37:389-398.

61. Etang J, Fondjo E, Chandre F, Morlais I, Brengues C, Nwane P, Chouaibou M, Ndjemai H, Simard F: First report of knockdown mutations in the malaria vector Anopheles gambiae from Cameroon. Am J Trop Med Hyg 2006, 74:795-797.

62. Cuamba N, Choi KS, Townson H: Malaria vectors in Angola: distribution of species and molecular forms of the Anopheles gambiae complex, their pyrethroid insecticide knockdown resistance $(\mathrm{kdr})$ status and Plasmodium falciparum sporozoite rates. Malar J 2006, 5:2.

63. Reimer L, Tripet F, Slotman M, Spielman A, Fondjo E, Lanzaro GC: An unusual distribution of the kdr gene among populations of Anopheles gambiae on the island of Bioko, Equatorial Guinea. Insect Mol Biol 2005, 14:683-688.

64. Diabate A, Dabire RK, Kim EH, Dalton R, Millogo N, Baldet T, Simard F, Gimnig JE, Hawley WA, Lehmann T: Larval development of the molecular forms of Anopheles gambiae (Diptera: Culicidae) in different habitats: a transplantation experiment. J Med Entomol 2005, 42:548-553.

65. Kaiser ML, Koekemoer LL, Coetzee M, Hunt RH, Brooke BD: Staggered larval time-to-hatch and insecticide resistance in the major malaria vector Anopheles gambiae S form. Malar J 2010, 9:360.

66. Choi KS, Spillings BL, Coetzee M, Hunt RH, Koekemoer LL: A comparison of DNA sequencing and the hydrolysis probe analysis (TaqMan assay) for knockdown resistance $(\mathrm{kdr})$ mutations in Anopheles gambiae from the Republic of the Congo. Malar J 2010, 9:278.

67. Chandre F, Dabire RK, Hougard JM, Djogbenou LS, Irish SR, Rowland M, N'Guessan R: Field efficacy of pyrethroid treated plastic sheeting (durable lining) in combination with long lasting insecticidal nets against malaria vectors. Parasit Vectors 2010, 3:65

68. Ahoua Alou LP, Koffi AA, Adja MA, Tia E, Kouassi PK, Kone M, Chandre F: Distribution of ace-1R and resistance to carbamates and organophosphates in Anopheles gambiae s.s. populations from Cote d'Ivoire. Malar J 2010, 9:167.
69. Ndiath MO, Brengues C, Konate L, Sokhna C, Boudin C, Trape JF, Fontenille D: Dynamics of transmission of Plasmodium falciparum by Anopheles arabiensis and the molecular forms $\mathrm{M}$ and $\mathrm{S}$ of Anopheles gambiae in Dielmo, Senegal. Malar J 2008, 7:136.

70. Moreno M, Vicente JL, Cano J, Berzosa PJ, de Lucio A, Nzambo S, Bobuakasi L, Buatiche JN, Ondo M, Micha F, Do Rosario VE, Pinto J, Benito A: Knockdown resistance mutations (kdr) and insecticide susceptibility to DDT and pyrethroids in Anopheles gambiae from Equatorial Guinea. Trop Med Int Health 2008, 13:430-433.

71. Dabire KR, Diabate A, Djogbenou L, Ouari A, N'Guessan R, Ouedraogo JB, Hougard JM, Chandre F, Baldet T: Dynamics of multiple insecticide resistance in the malaria vector Anopheles gambiae in a rice growing area in South-Western Burkina Faso. Malar J 2008, 7:188.

72. Cohuet A, Krishnakumar S, Simard F, Morlais I, Koutsos A, Fontenille D, Mindrinos M, Kafatos FC: SNP discovery and molecular evolution in Anopheles gambiae, with special emphasis on innate immune system. BMC Genomics 2008, 9:227.

73. Kleinschmidt I, Torrez M, Schwabe C, Benavente L, Seocharan I, Jituboh D, Nseng G, Sharp B: Factors influencing the effectiveness of malaria control in Bioko Island, equatorial Guinea. Am J Trop Med Hyg 2007, 76:1027-1032.

74. Yaro AS, Dao A, Adamou A, Crawford JE, Traore SF, Toure AM, Gwadz R, Lehmann T: Reproductive output of female Anopheles gambiae (Diptera: Culicidae): comparison of molecular forms. J Med Entomol 2006, 43:833-839.

75. Le Goff G, Leong Pock Tsy JM, Robert V: Molecular characterization of the malaria vector Anopheles gambiae s.s. in Madagascar. Med Vet Entomol 2006, 20:259-260.

76. Diabate A, Chandre F, Rowland M, N'Guessan R, Duchon S, Dabire KR, Hougard JM: The indoor use of plastic sheeting pre-impregnated with insecticide for control of malaria vectors. Trop Med Int Health 2006, 11:597-603.

77. Dabire RK, Diabate A, Baldet T, Pare-Toe L, Guiguemde RT, Ouedraogo JB, Skovmand O: Personal protection of long lasting insecticide-treated nets in areas of Anopheles gambiae s.s. resistance to pyrethroids. Malar $J$ 2006, 5:12.

78. Tripet $F$, Thiemann $T$, Lanzaro GC: Effect of seminal fluids in mating between $\mathrm{M}$ and $\mathrm{S}$ forms of Anopheles gambiae. J Med Entomol 2005, 42:596-603.

79. Czeher C, Labbo R, Arzika I, Duchemin JB: Evidence of increasing Leu-Phe knockdown resistance mutation in Anopheles gambiae from Niger following a nationwide long-lasting insecticide-treated nets implementation. Malar J 2008, 7:189.

doi:10.1186/1475-2875-10-215

Cite this article as: Santolamazza et al: Comparative analyses reveal discrepancies among results of commonly used methods for Anopheles gambiaemolecular form identification. Malaria Journal 2011 10:215.

\section{Submit your next manuscript to BioMed Central and take full advantage of:}

- Convenient online submission

- Thorough peer review

- No space constraints or color figure charges

- Immediate publication on acceptance

- Inclusion in PubMed, CAS, Scopus and Google Scholar

- Research which is freely available for redistribution

Submit your manuscript at www.biomedcentral.com/submit
C Biomed Central 